\title{
ISOLATION OF Streptomyces sp. FROM LAPINDO MUD SOIL, SIDOARJO, EAST JAVA PROVINCE, INDONESIA AS A LARVICIDE CANDIDATE AGAINST Aedes aegypti
}

\author{
Subagyo Yotopranoto ${ }^{1,2}$, Rochmah Kurnijasanti ${ }^{3}$, Etik Ainun Rohmah ${ }^{2}$ \\ ${ }^{1}$ Department of Parasitology, Faculty of Medicine, ${ }^{2}$ Laboratory of Entomology, Institute of Tropical Disease, \\ ${ }^{3}$ Department of Basic Veterinary Medicine, Faculty of Veterinary Medicine, Universitas Airlangga, Surabaya, \\ Indonesia
}

\begin{abstract}
ABSTRAK
Streptomyces sp. adalah suatu bakteri yang dapat hidup di banyak tempat habitat yaitu laut, bunga karang, daerah pantai, tanah, tanah pasir, tepi sungai dan lain-lain. Banyak antibiotika dan metabolit sekunder yang dihasilkan oleh bakeri ini. Beberapa metabolit sekunder dari bakteri ini dapat digunakan sebagai insektisida tehadap serangga termasuk larva nyamuk. Tujuan dari penelitian ini adalah untuk mencari dan mengisolasi sampai spesies dari Streptomyces sp. dari tanah lumpur Lapindo Sidoarjo, provinsi Jawa Timur yang dapat digunakan sebagai larvasida terhadap larva Aedes aegypti, vektor penyakit demam berdarah dengue. Metode penelitian ini adalah menumpulkan beberapa sampel tanah lumpur dari Lapindo Sidoarjo. Sampel yang sudah dikoleksi dikultur pada media ISP-4 untuk mendapatkan kultur campuran. Kemudin mengisolasi koloni yang dicurigai sebagai Streptomyces sp.dengan mengkultur beberapa kali lagi pada media ISP-4 pada petri dish. Beberapa isolat yang murni kemudian dikultur pada media ISP-4 miring (slant). Diperoleh delapan isolat murni Streptomyces sp. Karakterisasi $16 S$ sRNA dari Streptomyces sp. dilakukan dalam rangka untuk menentukan spesies. Isolasi DNA dikerjakan dan dilanjutkan dengan sekuensing DNA, kemudian dibandingkan dengan Gene Bank dengan menggunakan program BLAST. Hasilnya menunjukkan bahwa sekuens basa-basa nukleotida Streptomyces Sp-D6 menunjukkan kesamaan yang tinggi dengan Streptomyces sp. 171524, disamping itu sekuens basa-basa nukleotida Streptomyces SpD7 dan SP-D9 mempunyai kesamaan yang tinggi dengan Streptomyces sp. ACT-05178 dan ACT-175695.Tiga spesies ini dapat digunakan sebagai calon larvasida terhadap Ae. aegypti. (FMI 2017;53:118-123)
\end{abstract}

Kata kunci: isolasi Streptomyces sp, karakterisasi $16 S$ sRNA, lumpur Lapindo Sidoarjo, calon larvasida, larva Aedes aegypti

\begin{abstract}
Streptomyces sp. is a bacterium that can live in many kind of habitations e.i. marine, sea sponge, coastal area, soil, desert soil, river bank etc. Many antibiotics and secondary metabolites are produced by this bacterium. Several secondary metabolites of the bacterium can be used as an insecticide against insects including mosquito larva.The purpose of this study was to search and isolate until species of Streptomyces sp. from Sidoarjo Lapindo mud soil in East Java province that can be used as a larvicide against Aedes aegypti larva, the dengue haemorrhagic fever vector. The method of study was to collect several mud soil samples from Sidoarjo Lapindo. The collected samples were cultured in ISP-4 media for producing mix-cultures. Then, to isolate the suspected colony of Streptomyces sp. by culturing again in several replications on ISP-4 media in petri-dish. The pure isolates were cultured in ISP-4 slant media. There were could be obtained eight pure isolates of Streptomyces sp. The characterization of 16S rRNA of Streptomyces $s p$. was done in order to determine the species. DNA isolation was done and followed by DNA sequencing, then compared to Gene Bank with BLAST program. The results showed that the sequence nucleotide bases of Streptomyces Sp-D6 had high similarity to Streptomyces sp. 171524, beside the sequence nucleotide bases of Streptomyces Sp-D7 and Sp-D9 had high similarity to Streptomyces sp. ACT-01578 and ACT-175695. These three species can be used as larvicide candidate against Ae. aegypti. (FMI 2017;53:118-123)
\end{abstract}

Keywords: Streptomyces sp. isolation, $16 S$ rRNA characterization, Lapindo Sidoarjo mud soil, larvicide candidate, Aedes aegypti larva

Correspondence: Subagyo Yotopranoto, Department of Parasitology, Faculty of Medicine, Universitas Airlangga, Jalan Prof. Dr. Moestopo 47, Surabaya 60131, Indonesia. Phone: 031-5020251-3 Ext: 116/6281332342507, E-mail: parasitologifkua@yahoo.com

\section{INTRODUCTION}

The dengue haemorrhagic fever (DHF) is still a public health problem in the world and a lot of countries has been infected (Gubler 1996) including Indonesia. The DHF caused by dengue virus including in Flaviviridae family. Serologically consisted of four serotypes viz. Den-1, Den-2, Den-3 and Den-4 that have circulated in Indonesia (Aryati 2006, Setiati et al. 2009). The vector of DHF is mosquito of Aedes aegypti as the primary vector and Ae. albopictus as a secondary vector. In big city likes Surabaya the main vector of DHF is Ae. 
aegypti (Yotopranoto et al. 2003). The DHF is still a big problem in the world including Indonesia, because the anti-dengue virus drug and the vaccine to protect dengue virus infection are not discovered yet. Therefore, for protecting to dengue infection is directed to control the vector (Kusriastuti 2005).Usually the vector control can be directed against adult mosquito and larval stage.

There are several methods of vector control, viz. mechanical, chemical and biological measurements (Soegijanto 2004, Kusriastuti 2005, WHO 2010). Chemical insecticides are used for a long time for killing the adult mosquito and larval stage in a lot of places. These conditions can caused mosquito resistant to insecticides, environmental pollution, insecticide in-toxication, non target organism mortality (Indonesia Ministry of Health 2007, 2011). Calvanty et al (2007) showed that temephos can enter into food and accu-mulates in the human body.

A new effort must be done which is more effective, efficient and save to environment for controlling mos-quito is needed, one of it is Streptomyces as a natural product. Streptomyces can be isolated from many kind habitations viz. sea and sea sponge (Xiong et al. 2004, Dhanasekaran et al. 2010), mangrove land and marine soil (Vijayakumar et al. 2010, Naine and Devi 2014), soil (Anderson and Wellington 2001, Meyers et al. 2003), soil in forest (Jun et al. 2003), mud soil, river bank, soil in highland and high polluted soil, also desert soil (ElKawagh et al. 2011) and Purnomo (2012) has discovered Streptomyces from mud soil of Lapindo, Sidoarjo, Indonesia.

Streptomyces is a bacterium which is including in Actinobacteria, and has a larvicidal activity against mosquito Anopheles larva (Dhanasekaran et al. 2010), Arti et al. (2015) showed that a new strain of $S$. indiaensis (LMG19961) had a larvicidal activity against $A n$. stephensi and a probability save to environment. Vijayan and Balaraman (1991) showed that Actinomy-cetes and its derivatives are highly toxic to mosquitoes, besides low toxicity to non target organisms. Liu et al (2008) expressed that Actinomycetes may be a promising approach for mosquito control. El-Bendary et al. (2010) showed that S. microflavus had larvicidal activity against Culex pipiens. Streptomyces produces second-ary metabolites consisted of antibiotics and such substances that can act as insect larvicides viz. faerifungin, macrotetroloid, flavonoid and tetranectin (Vijayakumar et al 2010). The secondary metabolites of Streptomyces also act as anti-bacteria, anti-virus, antitumor and immunosuppressive agent.The antibiotics that can be produced by Streptomyces sp. are streptomycin, neomycin, kanamycin, nistatin, amphothericin
B, tetracycline, viomycin, etc (Hoopwood 1999). Gene Bank data until now has discovered 1,489 species of Streptomyces which consisted of 11 isolates from Indonesia and 1,478 isolates from world. Characterization by using $16 \mathrm{~S}$ rRNA gene can determine the species of Streptomyces. Based on the above mentions, this study was done for looking for new isolate of Streptomyces $s p$. based on the characteristics of sequence profile of gene of $16 \mathrm{~S}$ rRNA which was collected from Lapindo mud soil, Sidoarjo, and hopefully the determined species can survive and has a larvicidal activity against $A$ e. aegypti larva.

\section{MATERIALS AND METHODS}

\section{Study site and location of Lapindo mud soil}

Lapindo mud soil is located in Sidoarjo district. The distance is around $35 \mathrm{~km}$ southern part from Surabaya, the capital of East Java Province, Indonesia. Mud was spurted to come out from the hole of petroleum drilling mine since 2006 until now is still flowing covering to one subdistrict area.

\section{Soil samples}

Soil samples were collected from several parts of Sidoarjo Lapindo mud soil. The collected samples were sent to Pharmacology Laboratory, Faculty of Veterinary, Universitas Airlangga, Surabaya in order to culture and isolate the Streptomyces from mud soil samples.

\section{Culture of Streptomyces sp. isolate}

Based on Alexander and Strete (2001) method, each mud soil samples were cultured in ISP-4 (International Streptomyces Project-4) media in a petridish for 4 days to get mix-cultures. Then, Streptomyces sp. colonies were selected by taken one öse of each colony and cultured in ISP-4 hard media in a petridish, incubated for 4 days at $28^{\circ} \mathrm{C}$ done for seven replications. Next step, Streptomyces sp. cultures were transferred into ISP-4 slant agar media. According to Davelos et al. (2004) Streptomyces $s p$. isolates must be saved in ISP-4 liquid media which added $20 \%$ glycerol at temperature of $-80^{\circ} \mathrm{C}$ in order to prevent the morphological and physiological changes.

\section{Streptomyces sp. isolate identification}

According to Alexander and Strete method (2001), the morphological characteristics of Streptomyces sp. Colony macroscopically are as follow: small size 2-3 mm diameter, smooth leathery, look like skin and hard, spore is located on the end of aerial mycelia, colony 
likes powder granules or velvet, produces such kind of pigment and earthy aroma. Microscopy observation was done by taken one öse of Streptomyces $s p$. colony and put on an object glass with 1-2 drops of sterilized water under X400 magnification of lense. Gram staining also be done and examined under lense of X100-400 magnification. Carbohydrates tests using arabinose, lactose, xylose, mannitol, saccharose and amylum also be done in order to proof that Streptomyces $s p$. can using sugars for its development.

\section{Electrophoresis product of PCR of Streptomyces sp. isolate}

Amount of 0.4 Gram agarose (Gibco BRL, no. cat 15510-019) dissolved in $20 \mathrm{~mL}$ TBE X0.5 for getting $2 \%$ agarose gel. Agarose solution was warmed until boiling, besides preparing a template. Electrophoresis comb was put on to construct gel wells. After boiling, agarose solution was placed until reaching temperature of $60^{\circ} \mathrm{C}$, then added $0.5 \mu \mathrm{L} / \mathrm{mL}$ ethidium bromide. Agarose solution poured into prepared template and let it to harden. After that, cover of template and comb were taken. The template was placed in electrophoresis container which filled with X0.5 TBE. Then, $8 \mu \mathrm{L}$ PCR product was added and poured $2 \mu \mathrm{L}$ loading solution into electrophoresis wells. DNA marker also poured into one of the wells. Electrophoresis machine was handled on $100 \mathrm{~V}$ for 20 minutes. The results were seen under UV light.

\section{DNA purification}

PCR products were purified with QIA quick PCR Purification Kit. Before be used, added $96 \%$ ethanol on PE solution. Then, PB (5 times of volume) solution was added into the result of PCR product. Samples were put on QIA Quick spin column ( $2 \mathrm{~mL}$ collect tube) and was centrifuged for 30-60 seconds to catch DNA. After flow through was thrown, then centrifuged in 15,000 rpm for 1 minute. Upper portion was taken and poured into a 1.5 $\mathrm{mL}$ sterilized tube. Added EB buffer on central part of membrane and was leaved for 1 minute, then centrifuged again for 1 minute.

\section{DNA sequencing}

Template for sequencing is purified DNA of PCR product. Sequencing was done by Sanger method using ABI Prism 310 sequencer. Labeling by using big dye with volume of $150 \mu \mathrm{L}$ and $200 \mathrm{ng} / \mathrm{mL}$ concentration. For reading the result, samples were loading in all wells in Sequencer ABI Prism 310 machine with volume of $1.5 \mu \mathrm{L}$. The results of sequencing can be seen during few hours through the monitor seen as an allogram graph and could be printed.
Analysis the profile of gene 16S rRNA of Streptomyces $s p$. For analyzing DNA sequencing and amino acid translation was done using software of Bio Edit Sequence Alignment Editor Version 7.0.5.3. computer. Homology of sequence inter local isolates based on Gene Bank reference.

\section{RESULTS}

Isolation of Streptomyces sp. was done through several steps. First step was culturing Lapindo mud soil samples from Sidoarjo on ISP-4 media in petri dishes that yielded mix cultures as shown on Fig. 1.

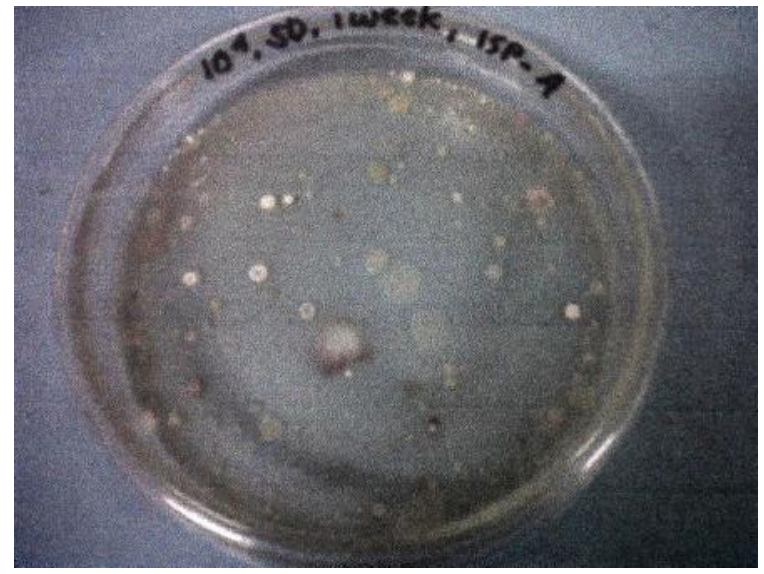

Fig. 1. Mix culture isolates from Sidoarjo Lapindo mud soil samples.

Isolation from colonies which were suspected as Streptomyces $s p$. followed by purification through replicated cultures on ISP-4 media in order to get pure isolates. Then, pure isolates were cultured in ISP-4 media agar slant. Obtained isolates will be used as samples for larvicidal activities against Ae. aegypti larva. There were 16 isolates succeeded to be isolated from Lapindo mud soil, but only eight isolates could develop well in ISP-4 media shown in Figure 2. The suspected Streptomyces sp. isolates showed colour variations from white, bony white until greyish white. Slide preparation for staining with Gram stain showed that Streptomyces sp. was rod bacteria and Grampositive stained.

\section{Result of characterization of $16 \mathrm{~S}$ rRNA Streptomyces $s p$. isolates of Sidoarjo Lapindo mud soil.}

Species identification of Streptomyces sp. was based on $16 \mathrm{~S}$ rRNA gene. The steps for characterization of $16 \mathrm{~S}$ rRNA of Streptomyces sp. consisted of DNA isolation of Streptomyces sp., electrophoresis of PCR product of Streptomyces $s p$., PCR amplification of $16 \mathrm{~S}$ rRNA, 
DNA purification of Streptomyces $s p$., and DNA sequencing. DNA sequencing results were compared to Gene Bank using BLAST Program.

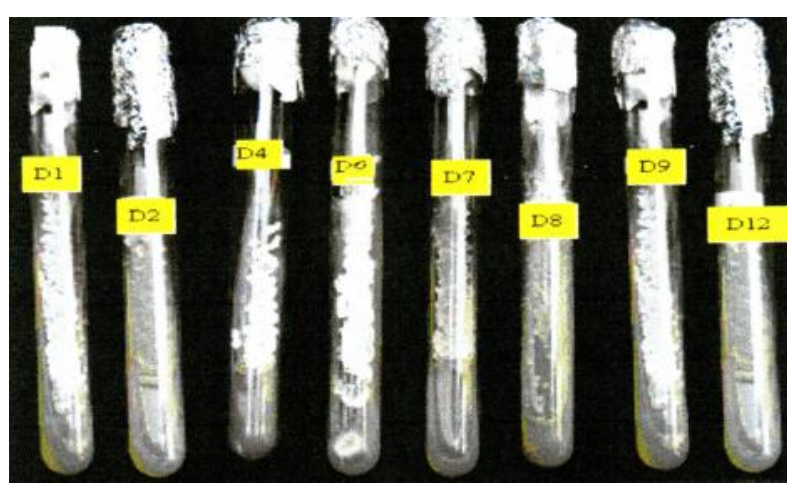

Fig. 2. The eight isolates of Streptomyces sp. named as Sp-D1, Sp-D2, Sp-D4, Sp-D6, Sp-D8, Sp-D9 and Sp-D12 yielded from Sidoarjo Lapindo mud soil isolation.

\section{Isolates resulted from PCR formula}

PCR result of isolates of Streptomyces sp. consisted of Sp-D1, Sp-D2, Sp-D4, Sp-D6, Sp-D7, Sp-D8, Sp-D9 and Sp-D12 shown in Figure 3.

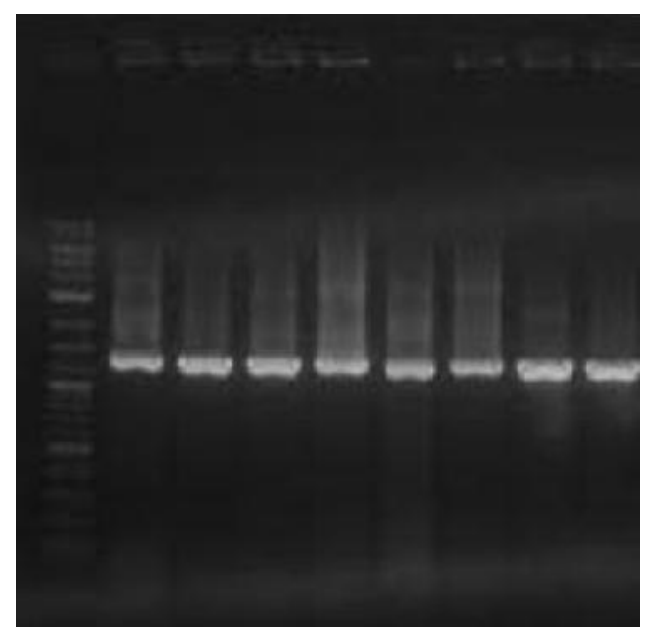

Fig. 3. PCR results of eight Streptomyces sp. isolates from Sidoarjo Lapindo mud soil.

From the agarose gel could be shown that eight of Streptomyces $s p$. isolates showed eight bands located at the same level. It meant the all isolates had similar character.

\section{Result of sequencing of $16 \mathrm{~S}$ rRNA gene}

Determination of sequence of 16S rRNA gene was done to three isolates of Streptomyces sp selected randomly in the first step viz. Sp-D6, Sp-D7 and Sp-D9. The other isolates will be identified in the following steps. Sequencing results showed the length of nucleotides sequence of Streptomyces Sp-D6, Sp-D7 and Sp-D9 were $1200 \mathrm{pb}, 1000 \mathrm{pb}$ and $750 \mathrm{pb}$ respectively. The sequencing results were compared to Gene Bank using BLAST Program. Sequence of nucleotide bases of Streptomyces Sp-D6 had highest similarity to Streptomyces sp. 172618 with score of similarity of base pair was 2002, besides sequence of nucleotide bases of Streptomyces Sp-D7 and Sp-D9 had highest similarity to Streptomyces sp. ACT-0095, with score of similarity of base pair were 1738 and 1447. The percentage of accuration of identification or maximum identify of Streptomyces Sp-D6, Sp-D7 and Sp-D9 isolates showed score of $97 \%, 96 \%$ and $99 \%$ respectively (Table 1 ).

Table 1. BLAST results of sequence of $16 \mathrm{~S}$ rRNA gene of three Streptomyces sp. to $16 \mathrm{~S}$ rRNA base data.

\begin{tabular}{clcc}
\hline Isolate & \multicolumn{1}{c}{ Identification } & $\begin{array}{c}\text { Max. } \\
\text { Score }\end{array}$ & $\begin{array}{c}\text { Max. } \\
\text { Identification }\end{array}$ \\
\hline Sp-D6 & $\begin{array}{l}\text { Streptomyces sp. 171524 } \\
\text { 16S ribosomal RNA gene, } \\
\text { partial sequence }\end{array}$ & 2002 & $97 \%$ \\
Sp-D7 & $\begin{array}{l}\text { Streptomyces sp. ACT- } \\
\text { 01578 16S ribosomal }\end{array}$ & 1738 & $96 \%$ \\
& $\begin{array}{l}\text { RNA gene, partial } \\
\text { sequence } \\
\text { Sp-D9 }\end{array}$ & & \\
& $\begin{array}{l}\text { Streptomyces sp. ACT- } \\
\text { 175695 16S ribosomal } \\
\text { RNA gene, partial } \\
\text { sequence }\end{array}$ & 1447 & $99 \%$ \\
\hline
\end{tabular}

Streptomyces Sp-D6 isolate was identical with Streptomyces sp. 171524 from Gene Bank, the maximum score was 2002 and maximum identification was $97 \%$. Streptomyces Sp-D7 and Sp-D9 isolates were identical with Streptomyces sp. ACT-01578 and ACT-175695 from Gen Bank, the maximum score were 1738 and 1447 and maximum identification were 96\% and 99\% respectively.

\section{DISCUSSION}

Lapindo, Sidoarjo mud soil actually consisted of many kinds of bacteria and after be purified by cuturing for several times in ISP-4 media in petridish could be isolated 16 Streptomyces sp. isolates and named as SpD1 unti Sp-D16. From the 16 isolates actually only eight isolates viz. Sp-D1, Sp-D2, Sp-D4, Sp-D6, Sp-D7, $\mathrm{Sp}-\mathrm{D} 8, \mathrm{Sp}-\mathrm{D} 9$ and Sp-D12 that could grow well in ISP4 agar slant and showed different colony colour viz. white, bony white and grayish white. From each isolate taken one öse for Gram staining and showing rod bacteria with blue colour that it meant Gram positive bacteria. 
Species identification using method based on characterization of 16S rRNA gene was done on colonies of SpD6, Sp-D7 and Sp-D9. DNA isolation was done by PCR and followed by DNA sequencing. Results of DNA sequencing were compared to Gen Bank using BLAST Program.. The results of sequencing showed that the length of nucleotides sequence of Streptomyces Sp-D6, Sp-D7 and Sp-D9 were $1200 \mathrm{pb}, 1000 \mathrm{pb}$ and $750 \mathrm{pb}$ respectively.

Sequence of nucleotide bases of Streptomyces Sp-D6 had highest similarity to Streptomyces sp. 171524 with score of similarity of base pair was 2002, besides the sequence of nucleotide bases of Streptomyces Sp-D7 and Sp-D9 had highest similarity to Streptomyces $s p$. ACT-01578 and ACT-175695, with score of similarity of base pair were 1738 and 1447. The percentage of accuracy of identification or maximum identify of Streptomyces Sp-D6, Sp-D7 and Sp-D9 isolates showed score of $97 \%, 96 \%$ and $99 \%$ respectively. Species identification by using that method as mention above proved that Streptomyces Sp-D6 that was isolated from Sidoarjo Lapindo mud soil was true as a species which had high similarity score (97\%) to Streptomyces sp. 171524 from the Gen Bank. Besides, the Streptomyces Sp-D7 and Sp-D9 which were isolated from Sidoarjo Lapindo mud soil had high similarity score $(96 \%$ and 99\%) to Streptomyces sp. ACT-01578 and ACT-175695 species from the Gen Bank. Therefore, the three species of Sp-D6, Sp-D7 and Sp-D9 were the species belonged to Streptomyces. El-Bendary et al (2010) studied on the morphological, physiological and chemotaxonomical characteristics of the isolated from sand samples of underground spring at Giza Governorate in Egypt revealed that it belongs to Streptomyces $s p$. and the species identification by using $16 \mathrm{~S}$ rDNA sequencing analysis could identify as Streptomyces microflavus.

As we know that Streptomyces $s p$. which were collected from several habitations for example from marine, sponge, sand, soil, mud soil proven had activity as insecticide, growth inhibitory bioactivities and larvicide against Helicoverpa armigera and Spodoptera litura (Arasu et al. 2013), larvicide against larval stage of several species of mosquitoes and other insects (Xiong and Kong, 2004; Vijayakumar et al 2010, El-Bendary et al 2010, El-Khawagh et al 2011, Saurav et al 2013, Naine \& Devi 2014). El-Bendary et al (2010) discovered one isolate named Ict-1 from eight isolates of actinomycetes that their extracellular secondary metabolites showed larvicidal activity against Culex pipiens.

Based on the data as mentioned above, therefore, the three species of Streptomyces Sp-D6, Sp-D7 and Sp-D9 that were isolated from Sidoarjo Lapindo mud soil suspected had larvicidal potency against insects, especially against larva of Ae. aegypti, $C x$. quinquefasciatus, An. stephensi etc. which can act as vector or transmitter of several diseases that hazardous to human health (El-Bendary et al, 2010; El-Khawagh et al 2011, Saurav et al 2013, Naine \& Devi 2014).

In Indonesia and especially in Surabaya city, the dengue haemorrhagic fever (DHF) is an endemic disease and causes a lot of victims. The disease is transmitted mostly by Ae. aegypti mosquito (Yotopranoto et al 2003). Until now controlling the disease is directed to the vector, because anti-viral drug and vaccine for protecting human to dengue virus infection are still not yet discovered, therefore for controlling the disease is concerning on the vector elimination. In this case, the Streptomyces Sp-D6, Sp-D7 and Sp-D9 hopefully can be used as alternative larvicide candidate against Ae. aegypti, the vector of DHF.

\section{CONCLUSIONS}

The results of research on Streptomyces $s p$. isolates collected from Sidoarjo Lapindo mud soil can be concluded that 1) there were eight Streptomyces $s p$. isolates could be isolated from mud soil that showed different characters of morphologically, 2) randomly three isolates viz. Sp-D6, Sp-D7 and Sp-D9 were selected from eight isolates and species identification by gene characterization of 16S rRNA of Streptomyces $s p$. by using Gen Bank and BLAST Program showed different species viz. Streptomyces Sp-D6 has high similarity (97\%) with Streptomyces sp. 171524, besides Streptomyces Sp-D7 and Sp-D9 have high similarity (96\% and 99\%) with Streptomyces sp. ACT-01578 and ACT$175695,3)$ the three species viz. Streptomyces Sp-D6, Sp-D7 and Sp-D9, were actually included in Streptomyces $s p$., therefore can be used as candidate larvicides against mosquito larvae including $A e$. aegpyti

\section{ACKNOWLEDGEMENT}

The authors are grateful to the Rector of Universitas Airlangga, Surabaya who provided the fasilities for handling this research through financial support of DIPA DITLITABMAS Fiscal year 2015 No. 519/ UN3/2015, dated March 26, 2015.

\section{REFERENCES}

Alexander SK, Strete D (2001). Microbiology: a photographic atlas for the laboratory. Boston, Addison Wesley Longman. Inc 
Anderson AS, Wellington MHE (2001). Review article the taxonomy of Streptomyces and related genera. International Journal of Systematic and Evolutionary Microbiology 51, 797-814

Arti P, Pryansh A, Devendra K (2015). A new bacterial strain Streptomyces indiaensis (LMG19961) and its larvicidal and histopathological effect against Anopheles stephensi: a malaria mosquito. Int. Res. J. Biological Sci 4, 43-48

Arasu MV, Al-Dhabi NA, Saritha V, et al (2013). Antifeedant, larvicidal and growth inhibitory bioactivities of novel polyketide metabolite isolated from Streptomyces sp. AP-123 against Helicoverpa armigera and Spodoptera litura. BMC Microbiology 13,105

Aryati (2006). Epidemiologi molekuler virus dengue di Indonesia. Dissertation, Universitas Airlangga, Surabaya

Davelos AL, Xiao K, Samac DA, Kinkel LL (2004). Spatial variation in the frequency and intensity of antibiotic interaction among Streptomyces in a prairie soil. Applied and Environmental Microbiology 70, 1051-1058

Dhanasekaran D, Sakthi V, Thajuddin N, Paanerselv A (2010). Preliminary evaluation of Anopheles mosquito larvicidal efficacy of mangrove Actinobacteria IJAPT, I, 374-381

El-Bendary MA, Rifaat HA and Keera AA (2010). Larvicidal activity of extracellular secondary metabolites of Streptomyces microflavus against Culex pipiens. Canadian Journal of Pure and Applied Sciences, 4, 1021-1026

El-Khawagh MA, Hamadah Kh Sh and El-Sheikh TM (2011). The insecticidal activity of Actinomycete metabolites against the mosquito Culex pipiens. Egypt. Acad. J. Biol. Sci. 4, 103-113

Gubler JD (1996). World disribution of dengue. Dengue Bulletin 20, 1-4

Hoopwood (1999). Genetic contributions to understanding polyketide synthases. Chemical Rev. 97, 24652497

Indonesia Ministry of Health (2007). Guidance of ecological aspect of vector behaviour. Ditjen PPM \&PL, Jakarta

Indonesia Ministry of Health (2011). Dengue haemorrhagic fever control module. Jakarta

Jun LW, Zhang LP, Xu P, et al (2003). Agromyces aurentiacus sp. nov. isolated from a Chinese primeval forest. Evol. Microbiology 53, 303-307
Kusriastuti R (2005). Epidemiologi penyakit demam berdarah dengue dan kebijakan penanggulannya di Indonesia. Simposium Dengue Control Update, Yogyakarta, Pusat Kedokteran Tropis UGM

Liu H, Qin S, Wang Y, Li W, Zhang J (2008). Insecticidal action of Quinomycin A from Streptomyces sp. KN-0647, isolated from a forest soil. World J. Microbiol. Biotechnol 24, 2243-8

Meyers PR, Porte DS, Omorogie C, et al (2003). Streptomyces speibonae sp. nov., a novel Streptomycete with blue substrate mycelium isolated from South African soil. International Journal of Systematic and Evolutionary Microbiology 53, 801-80

Naine SJ, Devi SB (2014). Larvicidal and repellent properties of Streptomyces sp. VITJS4 crude extract against Anopheles stephensi, Aedes aegypti and Culex quinquefasciatus (Diptera: Culicidae). Polish Journal of Microbiology 63, 341-348

Purnomo E (2012). Isolasi dan karakterisasi bakteri pendegradasi hidrokarbon pada isolat tanah lumpur Lapindo. Tesis. UB. 2012

Saurav K, Rajakumar G, Kannabiran K, et al (2013). Larvicidal activity of isolated compound 5-(2,4dimethylbenzyl) pyrrolidin-2-one from marine Streptomyces VITSVK5 sp. against Rhipicephalus (Boophilus) microplus, Anopheles stephensi, and Culex tritaeniorhynchus. Parasitol Res, DOI 10.1007/s00436-011-2682-z

Setiati T.E, Wagenar JFP, De Kruif MD, et al (2009). Changing epidemiology of dengue haemorrhagic fever in Indonesia. Dengue Bulletin 30, 1-14

Soegijanto S (2004). Demam berdarah dengue, tinjauan dan temuan baru di era 2003. Surabaya, Airlangga University

Vijayakumar R, Murugesan S, Cholarajan A, Sakthi V (2010). Larvicidal potentiality of marine Actinomycetes isolated from Muthupet Mangrove, Tamilnadu, India. International Journal of Microbiological Research 1, 179-183

Vijayan VK, Balaraman K (1991) Metabolites of fungi and actinobacteria active against mosquito larvae. Indian J. Med. Res. 93, 115

Xiong L, Li J, Kong F (2004). Streptomyces sp. 173, an insecticidal micro-organism from marine. Letters in Applied Microbiology 38, 32-37

Yotopranoto S, Subekti S, Rosmanida, Salamun, Soegijanto, S, Kawabata M, Dachlan YP (2003). Vector situation in dengue haemorrhagic fever endemic area's of Surabaya municipality, Indonesia. Indonesian Journal of Tropical Medicine 14, 146-154 